\title{
The impact of ETC/PCM solar energy storage on the energy performance of a building
}

\author{
Robert Sekret ${ }^{1, *}$, and Piotr Feliński ${ }^{2}$ \\ ${ }^{1}$ Czestochowa University of Technology, ul. J. H. Dąbrowskiego 69, 42-201 Czestochowa, Poland \\ ${ }^{2}$ SUNEX S.A., Piaskowa 7, 47-400 Racibórz, Poland
}

\begin{abstract}
The main goal of this investigation was to increase the solar fraction and reduce the demand for non-renewable primary energy in a building heating system. Thermal performance of the prototype evacuated tube solar collector/storage integrated with a PCM (ETC/PCM) was analyzed. Technical grade paraffin with onset melting point of $51.24^{\circ} \mathrm{C}$ was used as a PCM. It has been shown that the highest solar energy fraction in the building heating system was obtained with a thermal load of $40 \mathrm{~W} \cdot \mathrm{m}^{-2}$ and the highest the surface area of ETC/PCM aperture in relation to the heating surface area value of 0.2 . Lowering the heating system parameters from $45 / 35^{\circ} \mathrm{C}$ to $35 / 25^{\circ} \mathrm{C}$ allowed for an increase in heat output from solar energy in the range from $2.71 \%$ to $5.44 \%$. The largest increase in the solar fraction was in the range of the ratio of the surface area of the solar collector ETC/PCM aperture to the area of the heated building from 0.03 to 0.07 . In summary, obtained results indicated that the proposed solution allowed reduction of non-renewable primary energy demand in conceptual heating system from $6 \%$ to $27 \%$ depending on the heat load of the building and the aperture area of the ETC/PCM.
\end{abstract}

\section{Introduction}

Increasing the share of renewable energy sources in the energy demand of buildings is possible, among others by storing energy. Currently used classic heat storage technologies based on materials using sensible heat have insufficient energy density values. Increasing the mass of heat accumulating material is associated with additional space required to build a heat store, which is often unavailable and unfavorable from the economical point of view. Therefore, research is conducted on the possibilities of using in the process of heat storage in addition to the sensible heat, also latent heat (PCM) [1,2] or thermochemical reactions and sorption [3]. The high application potential of PCM in the building construction is described, among others, at work [4], where the possibilities of using PCM to reduce the energy demand in the building and reduction of greenhouse gas emissions are presented. The use of phasechange materials in active systems such as heating and cooling has been described in [5]. In each case, the use of phase-changing materials influenced on the improvement of thermal comfort (less temperature fluctuations of heated and cooled rooms). As indicated in [6-8], the use of phase-change material in a low-temperature heat storage system has contributed to

\footnotetext{
* Corresponding author: rsekret@is.pcz.czest.pl
} 
the increase in COP and SPF coefficients of heat pumps or thermal capacity of solar collectors. The test results [9-17] showed that heat storage using PCM in medium-temperature systems (temperature range $35-90^{\circ} \mathrm{C}$ ) co-operating with the heating system of the building also leads to increase the heat from renewable energy sources (RES). Among the phase-changing materials, many of the beneficial thermal and physicochemical properties have paraffins that do not have: corrosive activity, supercooling effect (occurs in a small, negligible degree) and phase segregation. In addition, they are not toxic and flammable at low temperatures. Paraffins are chemically and thermally stable substances, with relatively high heat phase transitions. In the case of building heating systems, PCM are often used in low temperature heat storage systems fed by solar collectors, where they are the heat pump's bottom source. The concept of using phase change materials in a construction and installation system with a seasonal heat storage system co-operating with solar collectors and a heat pump is presented in [6]. Paper [7] presents a comparison between various configurations of a construction and installation system using a heat pump and solar collectors. The proposed concept of combining a heat storage system in the ground and a storage tank with phase-changing material has contributed to the increase in the thermal efficiency coefficient COP of the heat pump compared to the ground storage system without phase change material and without solar collectors. However, attention should be paid to the problems arising from the complex construction of the tank for phase-change material. The presented work presents the effect of increasing the use of solar radiation energy and reducing the building's demand for non-renewable primary energy by using the integration of an evacuated tube solar collector with paraffin as a heat storage material.

\section{Object and methodology of research}

\subsection{Research object}

The research object was a one-family building with a heated area $A_{\mathrm{f}}$ of $150 \mathrm{~m}^{2}$. Two variants of the installation were used: variant I - heat pump with water storage tank and with a vertical ground heat exchanger (reference variant) and variant II - glycol-water heat pump with a ground heat exchanger and with an arrangement of evacuated tube solar collector system (ETC) with paraffin (PCM). The schematic diagram of the heating installations of the building is shown in Figure 1. The solar collector system with paraffin (5), which in the second variant was instead of the water storage tank (2), was connected to the central heating system (4) through a heat exchanger (6) and hydraulic distributors (3). The basic element of the system was an evacuated tube solar collector with paraffin (5). The selected type of ETC consisted of a hydraulic separator equipped with vacuum tubes with a cylindrical absorber and a heat pipe. The use of a cylindrical absorber allowed PCM to be placed inside the vacuum tube. Through the heat pipe, which used the heat of the evaporation/condensation phase transformation of the working medium in it, heat flowed from the absorber and ETC into the heat-transfer fluid circuit in the distributor. The cross section of the vacuum tube with paraffin is shown in Figure 2. As a PCM, hydrotreated paraffin was used. The selected paraffin had an onset melting point of $51.24^{\circ} \mathrm{C}$. The sensible heat of paraffin in the solid phase was $1.8 \mathrm{~kJ} \cdot \mathrm{kg}^{-1} \cdot \mathrm{K}^{-1}$ and was lower than in the liquid phase $\left(2.2 \mathrm{~kJ} \cdot \mathrm{kg}^{-1} \cdot \mathrm{K}^{-1}\right)$. The total heat of phase transitions (changes in the crystal structure and melting) of the paraffin sample tested was $217.63 \mathrm{~kJ} \cdot \mathrm{kg}^{-1}$. Detailed characteristics of the ETC/PCM tube solar collector storage system used in the tests are presented in $[18,19]$. 


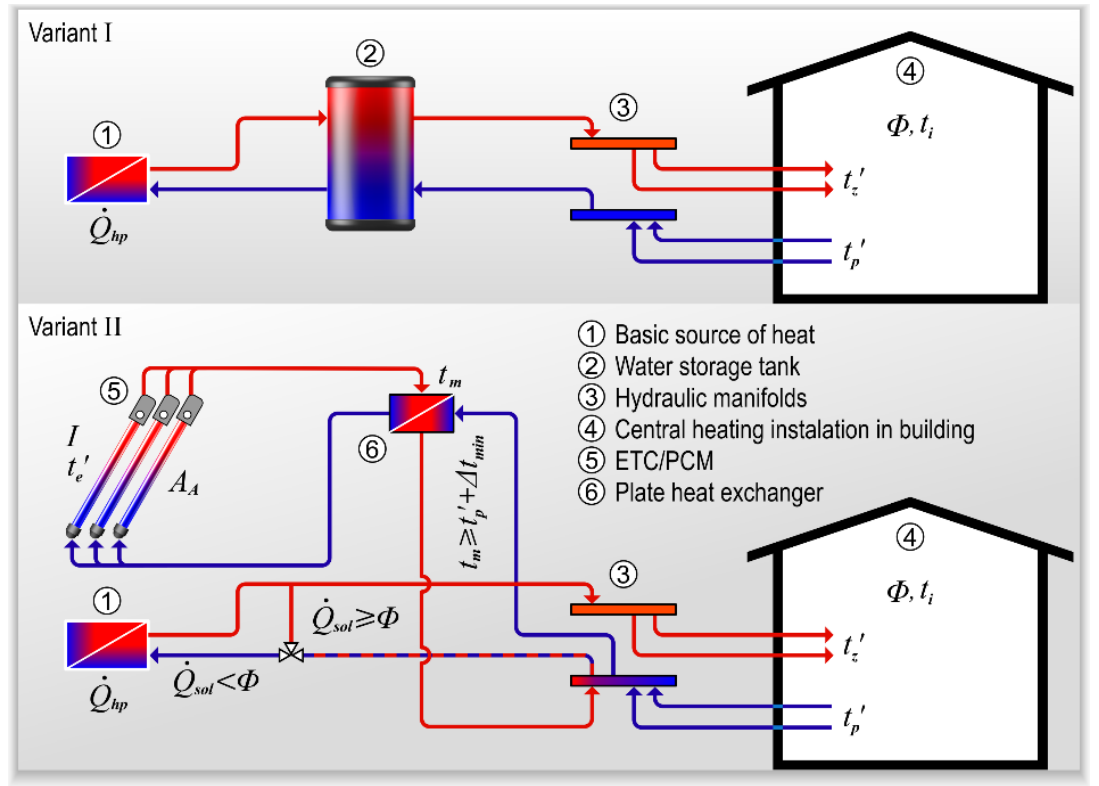

Fig. 1. Schematic diagram of the tested variants: a) reference variant I only with heat pump, b) variant II with an evacuated tube solar collector system (ETC) with paraffin (PCM) and heat pump

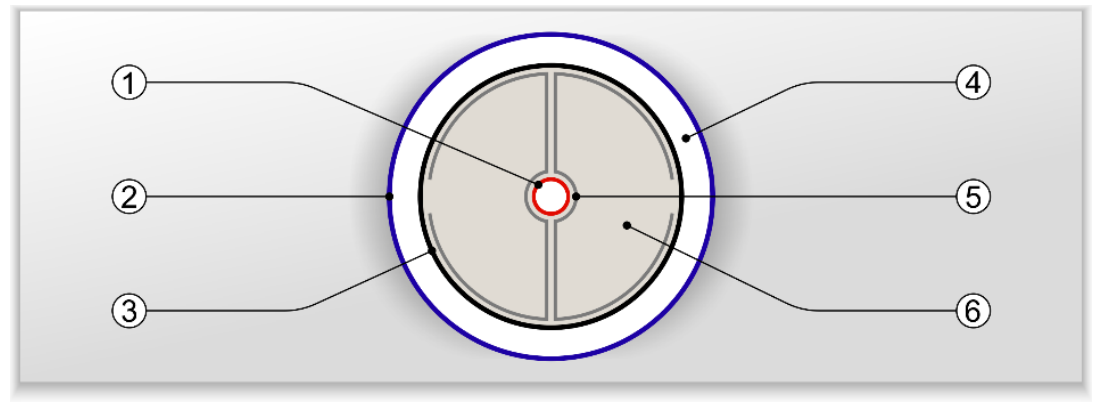

Fig. 2. Cross-section of vacuum tube with paraffin: 1 - heat pipe; 2 - glass cover; 3 - absorber; 4 - vacuum; 5 - profiled aluminum sheet; 6 - paraffin as PCM

\subsection{Research methodology}

Two types of low temperature installations for variant I and variant II were assumed, i.e. extremely low temperature $35 / 25^{\circ} \mathrm{C}$ (option A) and low temperature $45 / 35^{\circ} \mathrm{C}$ (option B). The calculations were made with the data of the third climate zone of Poland, i.e. the design external air temperature is $-20^{\circ} \mathrm{C}$. The building internal temperature was assumed $20^{\circ} \mathrm{C}$. The analysis was carried out for a building thermal load in the range from 10 to $100 \mathrm{~W} \cdot \mathrm{m}^{-2}$ and the area of the aperture of the ETC/PCM system $\mathrm{A}_{\mathrm{A}}$ in the range of 5 to $30 \mathrm{~m}^{2}$ (i.e. values $\mathrm{A}_{\mathrm{A}} / \mathrm{A}_{\mathrm{f}}$ from 0.03 to 0.2 ) supporting the heat pump. The building uses underfloor heating installation. Quality control of the heating system was assumed (constant mass flow and variable temperature of a heat fluid). It was assumed that evacuated tube solar collector with ETC/PCM paraffin (5) assisted the heat pump in the central heating system (4) when the temperature difference between the heat-transfer fluid in the ETC/PCM and the return fluid of the heating system was minimum $4 \mathrm{~K}$. This solar control system is shown at work [20]. 
The calculations were carried out for the period from September to May in the hourly time interval. The hourly demand for non-renewable primary energy for the heat pump (the heat pump compressor is supplied with electricity from the power network, that in Poland is $90 \%$ based on primary energy of hard coal and lignite) was determined (variant I A/B and variant II $\mathrm{A} / \mathrm{B})$ according to the equation:

$$
\begin{gathered}
\dot{Q}_{h p}=\sum\left[\frac{\Phi \cdot A_{f} \cdot\left(t_{z}^{\prime}-t_{p}^{\prime}\right)}{C_{0} P_{h p} \cdot \eta_{d, h p} \cdot \eta_{e, h p} \cdot \eta_{s, h p} \cdot\left(t_{z}-t_{p}\right)}+\dot{Q}_{p e s-i l, h p}\right] \\
t_{z}^{\prime}=t_{i}+\left(\frac{t_{z}+t_{p}}{2}-t_{i}\right) \varphi^{\frac{1}{n}}+\frac{t_{z}-t_{p}}{2} \varphi \\
t_{p}^{\prime}=t_{i}+\left(\frac{t_{z}+t_{p}}{2}-t_{i}\right) \varphi^{\frac{1}{n}}-\frac{t_{z}-t_{p}}{2} \varphi \\
\varphi=\frac{\left(t_{i}-t_{e}\right)}{\left(t_{i}-t_{e}\right)}
\end{gathered}
$$

where:

$\dot{Q}_{h p}$

$\Phi$

$A_{f}$

$t_{z}$

$t_{p}$

$t_{z}^{\prime}$

$t_{p}^{\prime}$

$t_{i}$

$t_{e}$

$t_{e}{ }^{\prime}$

$C O P_{h p}$

$\eta_{d, h p}$

$\eta_{e, h p}$

$\eta_{s, h p}$

$\dot{Q}_{p e s-i l, h p}$

$n$

- demand for non-renewable primary energy for heat pump for heating season, $\mathrm{kWh} / \mathrm{hs}$

- thermal load of building per unit of surface area, $\mathrm{W} \cdot \mathrm{m}^{-2}$

- area of heated building, $\mathrm{m}^{2}$

- design supply temperature of heating system, ${ }^{\circ} \mathrm{C}$

- design return temperature of heating system, ${ }^{\circ} \mathrm{C}$

- mean hourly supply temperature of heating system, ${ }^{\circ} \mathrm{C}$

- mean hourly return temperature of heating system, ${ }^{\circ}$

- internal air temperature in building, ${ }^{\circ} \mathrm{C}$

- design external air temperature, ${ }^{\circ} \mathrm{C}$

- mean hourly external air temperature, ${ }^{\circ} \mathrm{C}$

- coefficient of performance for heat pump, -

- efficiency of heat distribution in heating system, -

- efficiency of heat regulation and usage in heating system, -

- efficiency of heat stored in heating system and building, -

- non-renewable primary energy for internal load of heating system for heating season, $\mathrm{kWh} / \mathrm{hs}$

- coefficient of thermal characteristic of heating system type (value for underfloor heating installation $\mathrm{n}=1.1$ )

The equations 1 to 4 used for calculations are presented in detail at work [21]. The solar heat gain including distribution and regulation efficiency was determined in accordance with the equation:

$$
\dot{Q}_{s o l}=\sum\left[I \cdot A_{A} \cdot C O P_{h p, s o l} \cdot \eta_{d, s o l} \cdot \eta_{e, s o l} \cdot\left(1+\eta_{s, s o l} \cdot \eta_{d c h, s o l}\right)-\dot{Q}_{p e s-i l, s o l}\right]
$$

where:

$\dot{Q}_{\text {sol }} \quad-$ solar heat gain heat from ETC/PCM system for heating season, $\mathrm{kWh} / \mathrm{hs}$

I $\quad-$ hourly solar radiation, $\mathrm{kWh} \cdot \mathrm{m}^{-2}$ 
$A_{A} \quad-$ solar collector aperture area, $\mathrm{m}^{2}$

$C O P_{h p \text {,sol }}$ - coefficient of performance for heat pump in ETC/PCM system, -

$\eta_{d, \text { sol }} \quad-$ efficiency of heat distribution in ETC/PCM system, -

$\eta_{e, s o l}-$ efficiency of heat regulation and usage in ETC/PCM system, -

$\eta_{s, \text { sol }} \quad-$ efficiency of ETC/PCM charging, -

$\eta_{d c h, s o l}-$ efficiency of ETC/PCM discharging, -

$\dot{Q}_{\text {pes-il,so }}-$ non-renewable primary energy for internal load of ETC/PCM system for heating season, $\mathrm{kWh} / \mathrm{hs}$

The relative effect of reducing the demand for non-renewable primary energy of a heating system between variant I (heat pump only) and variant II (heat pump plus ETC/PCM) was calculated in accordance the equation:$$
E_{P E S}=\frac{\dot{Q}_{s o l, I I}}{\dot{Q}_{h p, I}} \cdot 100 \%
$$

The relative percentage effect of reducing the heating system's parameters from $45 / 35^{\circ} \mathrm{C}$ (option B) to $35 / 25^{\circ} \mathrm{C}$ (option A) for the obtained effect of the increase in the solar heat gain contribution in the heating system was calculated from the equation:

$$
E_{T H}=\left(100-\frac{\dot{Q}_{h p, I I-35 / 25}}{\dot{Q}_{h p, I I-45 / 35}}\right) \cdot 100 \%
$$

where:

$$
\begin{aligned}
E_{T H}- & \text { relative percentage effect of reducing the heating system's } \\
& \text { parameters, \% } \\
\dot{Q}_{h p, I I-35 / 2 !}- & \text { demand for non-renewable primary energy for heating for heating } \\
& \text { season in variant II, option A, i.e. heating system's parameters } \\
& 35 / 25^{\circ} \mathrm{C}, \mathrm{kWh} / \mathrm{hs} \\
\dot{Q}_{h p, I I-45 / 3 !}- & \text { demand for non-renewable primary energy for heating for heating } \\
& \text { season in variant II, option B, i.e. heating system's parameters } \\
& 45 / 35^{\circ} \mathrm{C}, \mathrm{kWh} / \mathrm{hs}
\end{aligned}
$$

\section{Results and analysis}

Figure 3 and Figure 4 show the relative effect of lowering the demand for non-renewable primary energy $\mathrm{E}_{\mathrm{PES}}$ as a result of using the ETC/PCM system. The results are presented for assumed $A_{A} / A_{f}$ as a function of the thermal load of building per unit of surface area for a $35 / 25^{\circ} \mathrm{C}$ and $45 / 35^{\circ} \mathrm{C}$ heating systems. With the increase of the surface area of the ETC/PCM aperture in relation to the surface area of the heated rooms, the effect $E_{\text {PES }}$ was increased for all the analyzed unit thermal loads of the building. On the other hand, with the increase in thermal load, for all the analyzed values of $A_{A} / A_{f}$, the solar energy fraction in the 
heat balance of the heating system was initially increased. Then, after reaching the maximum value, this effect decreased. The highest values of the relative effect of reducing the demand for non-renewable primary energy amounted to $27 \%$ for heating system $35 / 25^{\circ} \mathrm{C}$ (Figure 3 ) and $23 \%$ for heating system $45 / 35^{\circ} \mathrm{C}$ (Figure 4). These values were obtained with the thermal load of building per unit of surface area $\Phi$ of $40 \mathrm{~W} \cdot \mathrm{m}^{-2}$ and an $\mathrm{A}_{\mathrm{A}} / \mathrm{A}_{\mathrm{f}}$ value of 0.2 regardless of the heating system operation parameters. In the case of $A_{A} / A_{f}$ in the range from 0.03 to

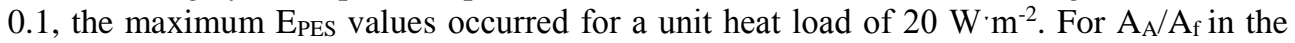
range from 0.13 to 0.17 , maximum $E_{P E S}$ values occurred for a unit heat load of $30 \mathrm{~W} \cdot \mathrm{m}^{-2}$.

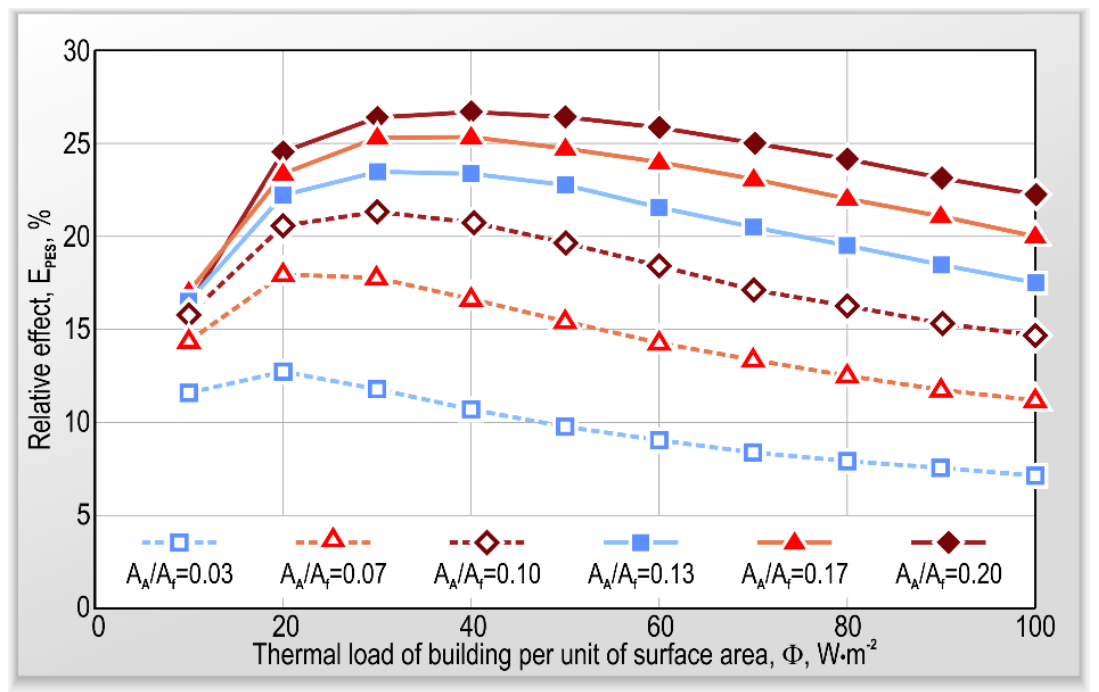

Fig. 3. The relative effect of reducing the demand for non-renewable primary energy depending on the thermal load of building per unit of surface area for heating system $35 / 25^{\circ} \mathrm{C}$ (option A)

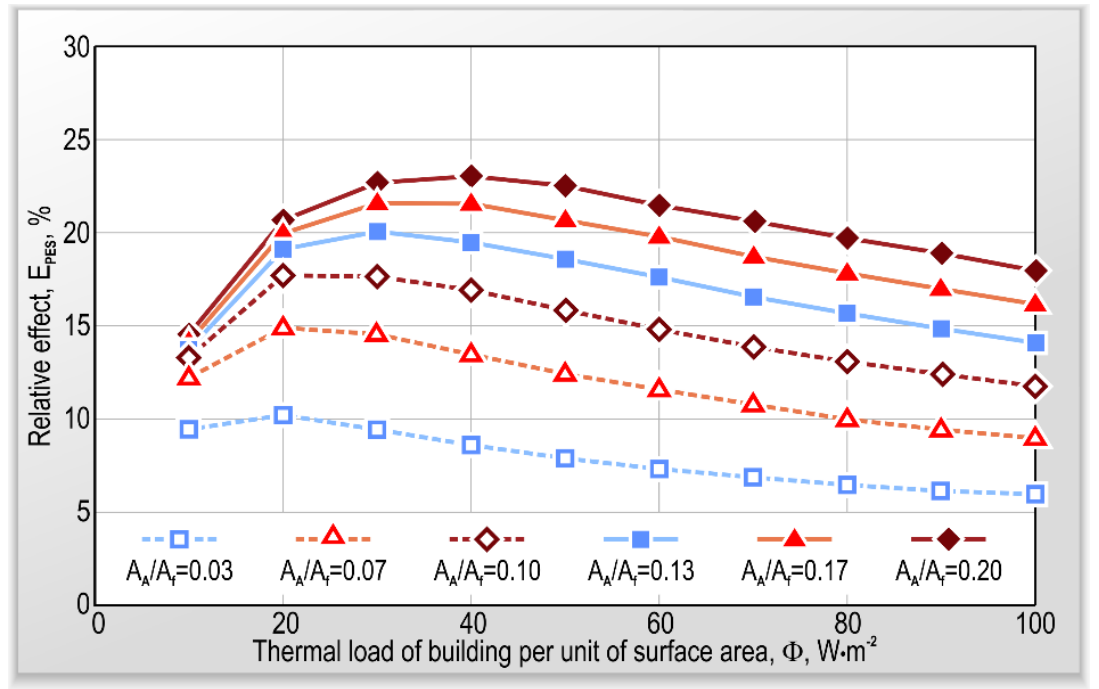

Fig. 4. The relative effect of reducing the demand for non-renewable primary energy depending on the thermal load of building per unit of surface area for heating system $45 / 35^{\circ} \mathrm{C}$ (option B) 
The lowest values of the effect of the proposed method of heat storage in the evacuated tube solar collector were caused by the fact that the majority of heat demand occurred mainly in the most adverse meteorological conditions, i.e. when ETC/PCM produced the least heat from the sun and lost the most heat as a result of losses. This applies mainly to periods of low external air temperatures and low hours of solar radiation. On the other hand, low heat demand in the period of favorable meteorological conditions (higher ambient temperatures, higher sums of solar radiation intensity) caused that the increase of the surface area of the ETC/PCM aperture in relation to the surface area of the heated rooms did not bring any significant effect. The largest increase in the relative effect of lowering $E_{P E S}$ was achieved by increasing the value of $\mathrm{A}_{\mathrm{A}} / \mathrm{A}_{\mathrm{f}}$ from 0.03 to 0.07 . The $\mathrm{A}_{\mathrm{A}} / \mathrm{A}_{\mathrm{f}}$ values above 0.13 did not significantly increase the relative effect of lowering the $E_{\mathrm{PES}}$ index. Figure 5 shows the relative effect of reducing the demand for non-renewable primary energy of a heating system between variant I (heat pump only) and variant II (heat pump plus ETC/PCM). As can be seen in Figure 5, the effect of choosing lower heating system's parameters increases with the increase of the aperture area and thermal load of the building. The obtained effect ranged from $2.71 \%$ to $5.44 \%$, respectively for the $\mathrm{A}_{\mathrm{A}} / \mathrm{A}_{\mathrm{f}}$ ratio 0.03 to 0.2 . The highest increase in the effect occurred in $A_{A} / A_{f}$ range from 0.03 to 0.07 (27\%) and from 0.07 to 0.10 (17\%).

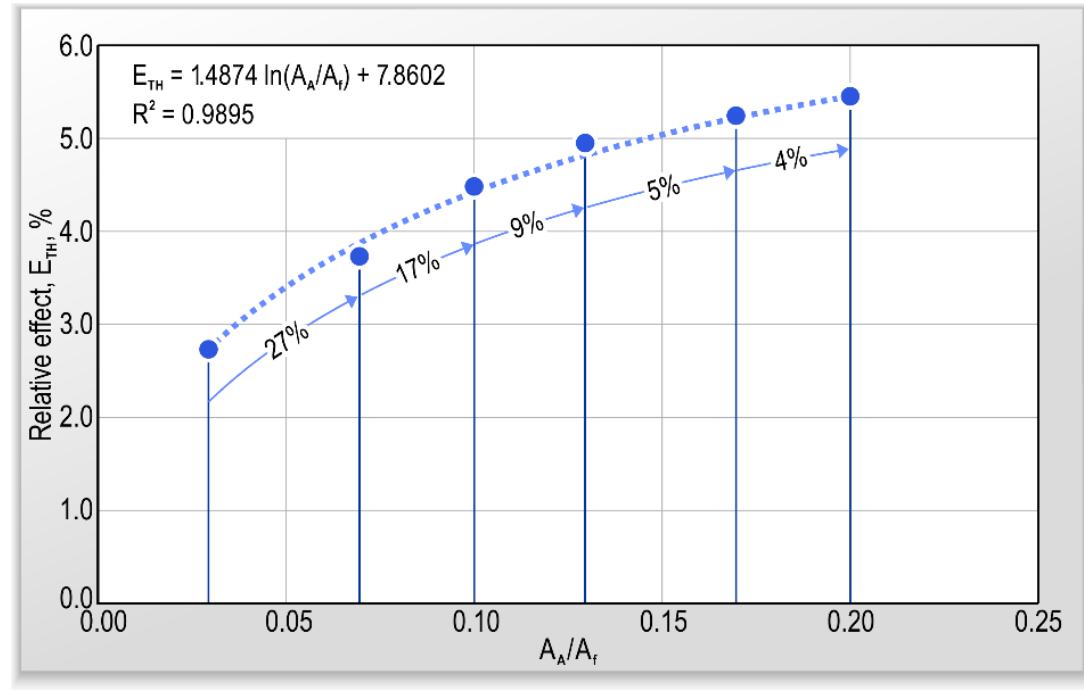

Fig. 5. Relative effect of lowering the heating system parameters depending on the ratio of the surface area of the solar installation aperture and the surface area of the heated building $\mathrm{A}_{\mathrm{A}} / \mathrm{A}_{\mathrm{f}}$.

\section{Summary}

Considering the increase in the solar energy fraction and the reduction of the demand for non-renewable primary energy in building heating systems, it is important not only to improve the efficiency of solar energy conversion, but also to store the heat generated. Limiting the time shift between the availability of solar energy and the heat demand for heating a building is possible by using latent heat. As a result, the heat generated during the maximum solar irradiance can be used during low or no solar radiation. The use of paraffin (an onset melting point of $51.24^{\circ} \mathrm{C}$ ) as a heat storage material in the ETC/PCM tube solar collector system allowed to reduce the demand for non-renewable primary energy and increase the solar energy fraction in a building heating system. This effect was in the range 
of $7-27 \%$ for heating system's parameters $35 / 25^{\circ} \mathrm{C}$ and $6-23 \%$ for heating system's parameters $45 / 35^{\circ} \mathrm{C}$. The highest effects of the reduction of the demand for non-renewable primary energy and the increase in the solar fraction were obtained with the thermal load of building per unit of surface area of 20 to $40 \mathrm{~W} \cdot \mathrm{m}^{-2}$. Lowering the heating system parameters from $45 / 35^{\circ} \mathrm{C}$ to $35 / 25^{\circ} \mathrm{C}$ allowed for an increase in heat output from solar energy in the range from $2.71 \%$ to $5.44 \%$. The largest increase in the solar fraction was in the range of the ratio of the surface area of the ETC/PCM aperture to the area of the heated building from 0.03 to 0.07 . Regardless of the heating system operation parameters, the ratio of the surface area of the tube solar collector system aperture to the area of the heated building values above 0.13 did not significantly affect the increase in the reduction of the demand for non-renewable primary energy of the building.

\section{References}

1. D. Zhou, C. Y. Zhao, Y. Tian Y, Appl. Energy 92, 593-605 (2012)

2. A. Sharma, V. Tyagi, C. R. Chen, D. Buddhi, Renew. and Sust. Energy Rev. 13, 318-345 (2009)

3. K. E. N'Tsoukpoe, H. Liu, N. Le Pierre 'S, L. Luo, Renew. and Sust. Energy Rev. 13, 2385-2396 (2009)

4. M. R. Anisur, M. H. Mahfuz, M. A. Kibria, R. Saidur, I. H. S. C. Metselaar, T. M. I Mahlia, Renew. and Sust. Energy Rev. 18, 23-30 (2013)

5. P. Feliński, R. Sekret, Energy and Build. 152, 558-567 (2017)

6. Q. Qi, S. Deng, Y. Jiang Y, Solar Energy 82, 669-675 (2008)

7. Z. Han, M. Zheng, F. Kong, F. Wang, Z. Li, T. Bai, Appl. Ther. Engin. 28, 1427-1436 (2008)

8. J. Tamasauskas, M. Poirier, R. Zmeureanu, R. Sunye, Solar Energy 86, 3316-3325 (2012)

9. L. F. Cabeza, M. Ibanez, C. Sole, J. Roca, M. Nogues, Solar Ener. Mater and Solar Cells 90, 1273-1282 (2006)

10. S. Canbazoglu, A. Sahinaslan, A. Ekmekyapar, Y. G. Aksoy, F. Akarsu, Energy and Build. 37, 235-42 (2005)

11. J. Prakash, H. P. Garg, G. Datta, Ener. Conv. Manag. 25, 51-56 (1985)

12. D. Haillot, E. Franquet, S. Gibout, J. Bedecarrats, Appl. Energy 109, 470-475 (2013)

13. X. Liu, G. Fang, Z. Chen, Appl. Therm. Engin. 31, 2902-2908 (2011)

14. Y. Rabin, I. Bar-Niv, E. Korin, B. Mikic, Solar Energy 55, 435-444 (1995)

15. A. Kurklu, A. Ozmerzi, S. Bilgin, Renew. Energy 26, 391-399 (2002)

16. M. Chaabane, H. Mhiri, P. Bournot, Ener. Conv. and Manag. 78, 897-903 (2014)

17. S. Tarhan, A. Sari, M. H. Yardim, Ener. Conv. and Manag. 47, 2143-2154 (2006)

18. P. Feliński, R. Sekret, Solar Energy 144, 758-766 (2017)

19. P. Feliński, R. Sekret, Energy, 114, 1063-1072 (2016)

20. R. Mazarrón, C. J. Porras-Prieto, J. L. García, R. M. Benavente, Ener. Conv. and Manag. 113, 16-26 (2016)

21. P. Feliński, Heat storage in a tube solar collector using paraffin for need of heating systems (PhD Thesis, Czestochowa University of Technology, Poland, 2016) 